\title{
Spinal Dysraphism: Presentation, Management and Outcome of Patients undergoing Surgery
}

\author{
Dr. Vipul Kumar Gupta ${ }^{1}$, Dr. Ankur Bhat ${ }^{2}$, Shilpi Sharma ${ }^{3}$, Dr. Bhumika Gupta ${ }^{4}$ \\ ${ }^{1}$ Consultant Lect. Department of Neurosurgery, GMC Jammu \\ ${ }^{2}$ Postgraduate Student Department of Surgery, GMC Jammu \\ ${ }^{3}$ Research Scientist Department of Microbiology, GMC Jammu \\ ${ }^{4}$ Consultant Lect. Department of CTVS, GMC Jammu
}

*Corresponding Author: Dr. Ankur Bhat; drankurbhat9213@gmail.com

Received: 09 July 2021;

Accepted: 12 August 2021;

Published: 15 August 2021

\begin{abstract}
The development of the spinal cord can be summed up in three developmental stages: gastrulation (2-3 weeks), primary neurulation (3-4 weeks) and secondary neurulation (5-6 weeks). Any sort of deviance in any of these stages causes anomalies in spine and spinal cord; these anomalies are referred as spinal dysraphism. The approximated incidence of spinal dysraphism is about 1/1000 live births. The present study aims at varied presentations, management and surgical consequences in spinal dysraphism. Methods: A study on surgical treatment of spinal dysraphism was done over the period of 6 months from December 2019- May 2020 at GMC, Jammu. In the study at hand; the clinical aspects, management and surgical outcomes in case of spinal dysraphism were characterized. Results: A total of 30 patients of spinal dysraphism were operated with $70 \%$ males and $30 \%$ females. The age group selected for the study was between 0-3 years. In early post-operative period the most common symptoms were found to be meningitis (6\%), minor wound infection (10\%), major wound infections (14\%) and 14\% patients reported CSF leakage. Out of 30 patients who underwent surgery, $67 \%$ patients had good outcome, $20 \%$ reported satisfactory outcome and $13 \%$ reported poor outcome with an overall mortality rate of $13 \%$. Conclusion: Spinal dysraphism is a complex disorder and requires a multidisciplinary approach for management. The present study suggests that surgery is the prominent treatment along with good post-operative care for the better life of the patient.
\end{abstract}

Keywords: Spinal dysraphism, Myelomeningocele, surgery

\section{Introduction}

Spinal dysraphism postulates an array of congenital abnormalities leading to a defective neural arch along which the meninges are herniated causing various clinical manifestations (Warner et al., 2019). These malformations of the spine and the spinal cord occur between the third and fourth week of gestation (Trapp et al., 2021). The term spinal dysraphism conclude the set of defects inferred from the abnormal development of ectoderm, mesoderm and endoderm tissues and its outcome might affect brain, extremities, bones, bladder and bowel functions. These de-formalities are classified into aperta (visible lesion) and occulta (with no external lesion) (Premlal et al., 2018). The calculated rate of incidence of the disease is $1-3 / 1000$ live births. The disease is found to be more prevalent in female newborns $1.0-1.7$ than male, 1.0 (Venkataramana, 2011).

Spinal dysraphism arise from a very early event in the embryonic development. Around third week of the developmental stage, the neutal plate folds up to form neural tube. The crown of the neural tube forms the head and the remaining tube develops into the spinal cord and the spine (Eagles and Gupta, 2020). Spinal dysraphism occurs when a segment of the neural tube, to be developed into the spine doesn't close completely (Blount et al., 2019). Depending on the anomalies caused in the spinal cord, the spinal dysraphism is divided into many types such as myelomeningocele (spina bifida), diastematomyelia (split cord malformation), lipomyelomeningocele (spinal cord lipoma), tight filum terminale, dermal sinus tract and tethered spinal cord (Aurel and Livii, 2020).

Of all the types, Myelomeningoceles or the spina bifida is the most common type of spinal dysraphic conditions impacting the lower urinary tract (Thompson, 2014). The term spina bifida comes from the latin, meaning, open spine. The incidence of spina bifida is approximately 1 in 1200 to 1400 births (Iftikhar and De Jesus, 2020). It is usually associated with skin defects with CSF leak risks. The open spina bifida is also the most severe form of spinal dysraphism. The condition is associated with poor ability to walk, impaired bowel and bladder conditions and hydrocephalus (accumulation of fluids in brain). The majority of the kids with spina bifida have normal intelligence. Though there are reports of children affected with spina bifida having learning disability (Sims-Williams et al., 2017).

Spinal dysraphia occulta are the closed form of spinal dysraphism. In this form, the skin forms a layer over the neural 
tissues. In majority of the cases, a skin marker is found to be present (Dias and Rizk, 2019). The recognition of these markers is essential to understand the type of dysraphism. These cutaneous marks can induce a spinal cord injury leading to progressive or sudden neurological deterioration. These marks can be in the form of hairy patch, an appendage, skin tag, cutaneous nevus, small dimple with a pinhole or a lipoma. Occult spinal dysraphism can be of varied embryologic etiologies but mostly they are associated with tethering of the spinal cord. The most common occulta forms are lipomas, diastematomyelia, diplomyelia, split cord malformations and dermoid tumors (Bradko et al., 2019).

For the diagnosis of the disease in utero, prenatal testing for neurological anomalies can be done using ultrasound or by maternal Alpha Feto Protein (AFP) screening. It has been reproetd that females bearing fetus with spina bifida has elevated levels of AFP and reduced levels of Human chorionic gonadotropin (HCG) and un-conjugated estriol (Reghunath et al., 2019). The maternal serum testing can detect $80 \%$ cases of spina bifida. Whereas, sonography can detect upto $90 \%$ cases of spina bifida. The testing for in utero defects should be done at 12, 22 and 32 weeks. The maternal periconceptional intake of folic acid has been known to reduce the incidence of spina bifida (Gotha et al., 2020). Other strategies to investigate spina bifida are by Magnetic Resonance Imaging (MRI), Doppler study of brain for resistive index of vessel to check for hydrocephalus and Chiari malformation, Computed Tomography (CT) to check for hydrocephalus, the maternal serum testing for chromosomal anomalies is also used (Szopa et al., 2020).

The children affected with spinal dysraphism reported to have a greater risk for showing worse levels of internalizing symptoms and low self esteem as compared to normal children. They are also found to be socially immature and interpersonally dry. Spinal dysraphia affected children with hydrocephalus, shown to have difficulties in academics (Prakash et al., 2018). They have also shown deficits in abstract reasoning, executive functioning and low focus. Children having a positive environment at home and support from parents have known to improve in the living quality by $25 \%$.

Management of the children affected with spinal dysraphism needs multidisciplinary approaches. Complete clinical investigation is mandatory (Tuite et al., 2018). The standard treatment for any type of spinal dysraphism is surgery after delivery (Peralta et al., 2020). The surgery is needed to control further damage to nervous tissue and manage infection. Pediatric neurosurgeons operate to seal the opening. Spinal cord and nerve roots are assembled back into the spine and are covered with meninges. In case of hydrocephalus, a shunt is surgically installed to remove excessive cerebrospinal fluids from the brain (Gordon et al., 2019). Parental counseling should be done for long-term management.

\section{Aim}

The aims and objectives of the present study is to evaluate:

- The clinical presentation of the patients with spinal dysraphism

- Other associated congenital anomalies

- The surgical management and outcomes of patients with spinal dysraphism

\section{Materials and Methods}

A study on surgical treatment of spinal dysraphism was done over the period of 6 months from December 2019- May 2020 at GMC,
Jammu. In the study at hand; the clinical aspects, management and surgical outcomes in case of spinal dysraphism were characterized. A total of 30 patients of spinal dysraphism were operated with $70 \%$ males and $30 \%$ females. The age group selected for the study was between 0-3 years.

In the present study, the most common site for swelling was found to be in lumbosacral region, followed by lumbar region, then thoracic region and lastly thoracolumbar region. No patient with cervical lesion was observed. Mothers underwent antenatal ultrasound to detect the anomaly.

After the patient was admitted, the following procedure was followed:

- The exposed nerves and tissue through the defect from trauma and infection was achieved by intravenous antibiotic administration and saline dressing.

- All the patients were treated in pediatric surgery operation theater

- The patient was positioned in prone manner and general anesthesia was administrated

- Elliptical incision was given over the swelling

- Then arachnoid was lifted in a circumferential fashion giving attention to the vascular supply to the placode.

- Careful and precise separation of the neural tissue from cutaneous tissue was done.

- A thorough search for associated anomialies such as tethering, diastermatomyelia, thick filum terminale, dermal sinus tract was carried out and was corrected.

- $\quad$ Re-tethering was prevented by taking precautions such as: pial closure to cover the raw dorsal surface of the cord and/ or duroplasty to enlarge the subarachnoid spaces to facilitate free CSF around repair surface.

- After freeing neural placode, it was inverted and sutured.

- Finally, dura was closed and covered with overlying skin.

- Patients with large defects underwent flap repair.

- Majority of patients were put on Tablet Diamox for conservative management.

- In case of hydrocephalus, simultaneous ventriculoperitoneal (V-P) shunting was done.

- The patients were nursed in prone position postoperatively to prevent wound contamination.

- IV antibiotics were given for 3-5 days post-operatively.

- They were regularly monitored on the basis of general conditions and systematic examination of motor, sensory and sphincteric functions.

- $\quad$ On 7th day patients were discharged.

- The follow up was made weekly for first month, then monthly for consecutive three months and three monthly thereafter.

\section{Results}

A total of 30 patients were selected in this study. The age ranged from 1-3 years.

Table 1: Sex, Age distribution and site of lesion of 30 patients taken for the present study

\begin{tabular}{|l|l|}
\hline Gender & No. of Cases \\
\hline Males & 21 \\
\hline Females & 9 \\
\hline Site of lesion & No. of Cases \\
\hline
\end{tabular}




\begin{tabular}{|l|l|}
\hline cervical & 0 \\
\hline Thoracic & 04 \\
\hline Thoracolumbar & 02 \\
\hline Lumbar & 05 \\
\hline Lumbosacral & 19 \\
\hline Age group & No. of Cases \\
\hline Neonates (<1 month) & 17 \\
\hline Infants (1month-1 year) & 6 \\
\hline Pre-school children $(1-3$ years) & 2 \\
\hline School going children $(>3$ years) & 5 \\
\hline
\end{tabular}

Table 1 shows that the incidence is high in males (number of cases $=21$ ), $70 \%$ when compared to females (number of cases $=9$ ), $30 \%$. Children below the age of 1 month were mostly affected (number of cases=17). Most of the patients were neonates, about $57 \%$ followed by infants upto $20 \%$, pre-school children about $6 \%$ and school going children around $17 \%$. In the present study, lumbosacral region was the most common site of swelling as seen in $63 \%$ patients followed by lumbar region $(17 \%)$, thoracic region (14\%) and thoracolumbar region (6\%). No patient with cervical lesion was reported.

Table 2: Various presentations of the patients with spinal dysraphism at the hospital

\begin{tabular}{|c|c|c|c|c|c|}
\hline S.No. & \multicolumn{3}{|l|}{ Clinical features } & No. of cases & $\%$ of cases \\
\hline 1 & \multicolumn{3}{|l|}{ Swelling of back } & 28 & 94 \\
\hline 2 & \multicolumn{3}{|l|}{ CSF leaks } & 14 & 47 \\
\hline \multirow[t]{3}{*}{3} & \multirow[t]{3}{*}{ In continence } & \multicolumn{2}{|c|}{ Both bladder and bowel } & 9 & 30 \\
\hline & & \multicolumn{2}{|l|}{ bladder } & 1 & 3 \\
\hline & & \multicolumn{2}{|l|}{ bowel } & 0 & 0 \\
\hline \multirow[t]{2}{*}{4} & Upper limb weakness & & & 0 & 0 \\
\hline & Upper limb deformity & & & 0 & 0 \\
\hline \multirow[t]{6}{*}{4} & \multirow{6}{*}{$\begin{array}{l}\text { Lower limb weakness (power } \\
<3 / 5 \text { ) }\end{array}$} & \multirow[t]{2}{*}{ Hip } & Right & 9 & 30 \\
\hline & & & Left & 9 & 30 \\
\hline & & \multirow[t]{2}{*}{ Knee } & Right & 15 & 50 \\
\hline & & & Left & 13 & 43 \\
\hline & & \multirow[t]{2}{*}{ Ankle } & Right & 15 & 50 \\
\hline & & & Left & 13 & 43 \\
\hline \multirow[t]{3}{*}{5} & \multirow{3}{*}{$\begin{array}{l}\text { Lower limb deformity (club } \\
\text { foot) }\end{array}$} & \multicolumn{2}{|l|}{ Bilateral } & 1 & 3 \\
\hline & & \multicolumn{2}{|l|}{ Right-sided } & 1 & 3 \\
\hline & & \multicolumn{2}{|l|}{ Left- sided } & 0 & 0 \\
\hline \multirow[t]{4}{*}{6} & \multirow{4}{*}{ Spine deformity } & \multicolumn{2}{|l|}{ Absent vertebrae } & 7 & 23 \\
\hline & & \multicolumn{2}{|l|}{ Hemi-vertebrae } & 2 & 6 \\
\hline & & \multicolumn{2}{|l|}{ Kyphosis } & 0 & 0 \\
\hline & & \multicolumn{2}{|l|}{ scoliosis } & 1 & 3 \\
\hline \multirow[t]{3}{*}{7} & \multirow{3}{*}{ Hydrocephalus } & \multicolumn{2}{|l|}{ Mild } & 7 & 23 \\
\hline & & Moderate & & 13 & 44 \\
\hline & & Severe & & 3 & 10 \\
\hline 8 & & hypertrichiosis & & 2 & 6 \\
\hline & Other stigmata & Sacral dimple & & 2 & 6 \\
\hline & & Hemangiomatou & & 1 & 3 \\
\hline 9 & & Anorectal malfo & & 1 & 3 \\
\hline & Other associated anomalies & Posterior urethra & & 1 & 3 \\
\hline & & hydroureteronep & & 4 & 14 \\
\hline & & Chest wall defor & & 1 & 3 \\
\hline & & Single kidney & & 1 & 3 \\
\hline & & hypospadias & & 2 & 6 \\
\hline & & Inguinal hernia & unilateral & 2 & 6 \\
\hline & & & bilateral & 1 & 3 \\
\hline & & Dermal sinus & & 3 & 10 \\
\hline
\end{tabular}

In the current study, $94 \%$ patients presented to hospital reported swelling in the back, $47 \%$ patients reported with CSF leaks. In the present study, $30 \%$ patients reported with bladder and bowel incontinence, $3 \%$ had bladder incontinence but no case of bowel incontinence was reported. No patient with upper limb weakness or deformity was observed. Lower limb weakness and deformities were observed and reported in table 2. Hydrocephalus was reported in $77 \%$ patients. A majority of the patients responded well to the treatment of Diamox (acetyl choline esterase inhibitor). Other stigmata of spinal dysraphism are reported in table 2.
Table 3: Power in lower limbs in patients with spinal dysraphism

\begin{tabular}{|l|c|c|c|}
\hline Region & Grade & $\begin{array}{c}\text { No of cases on } \\
\text { right side }\end{array}$ & $\begin{array}{c}\text { No of cases on } \\
\text { Left side }\end{array}$ \\
\hline Hip & 0 & 0 & 0 \\
\cline { 2 - 4 } & $1 / 5$ & 3 & 5 \\
\cline { 2 - 4 } & $2 / 5$ & 1 & 1 \\
\cline { 2 - 4 } & $3 / 5$ & 5 & 3 \\
\cline { 2 - 4 } & $4 / 5$ & 2 & 1 \\
\cline { 2 - 4 } & $5 / 5$ & 19 & 20 \\
\hline Knee & 0 & 6 & 3 \\
\cline { 2 - 4 } & $1 / 5$ & 2 & 6 \\
\hline
\end{tabular}




\begin{tabular}{|l|c|c|c|}
\hline \multirow{4}{*}{} & $2 / 5$ & 3 & 0 \\
\cline { 2 - 4 } & $3 / 5$ & 4 & 4 \\
\cline { 2 - 4 } & $4 / 5$ & 3 & 3 \\
\cline { 2 - 4 } & $5 / 5$ & 12 & 14 \\
\hline Ankle & 0 & 6 & 6 \\
\cline { 2 - 4 } & $1 / 5$ & 5 & 3 \\
\cline { 2 - 4 } & $2 / 5$ & 3 & 1 \\
\cline { 2 - 4 } & $3 / 5$ & 1 & 3 \\
\cline { 2 - 4 } & $4 / 5$ & 3 & 3 \\
\cline { 2 - 4 } & $5 / 5$ & 12 & 14 \\
\hline
\end{tabular}

In the present study, no patient with 0 power at hip in both the lower limbs was observed. Various findings with power in lower limbs in patients with spinal dysraphism are reported in Table 3.

Table 4: Antenatal ultrasound done in mothers to detect anomalies

\begin{tabular}{|c|c|c|c|}
\hline \multicolumn{2}{|c|}{ Antenatal ultrasound done } & No of patients & $\%$ \\
\hline \multicolumn{2}{|c|}{ Not done } & 6 & 20 \\
\hline \multirow[t]{2}{*}{ Done } & Anomaly detected & 18 & 60 \\
\hline & Not detected & 6 & 20 \\
\hline
\end{tabular}

In the present study $80 \%$ mothers underwent antenatal ultrasound, the anomalies were diagnosed in $60 \%$ mothers whereas, in $20 \%$ mothers, no anomalies were detected (Table 4).

Table 5: Folic acid intake of mothers

\begin{tabular}{|l|c|c|}
\hline Folic acid intake & No of cases & \% \\
\hline taken & 16 & 53 \\
\hline Not taken & 14 & 47 \\
\hline
\end{tabular}

In the present study, 53\% mothers were reported to be taking folic acid antenatally whereas, $47 \%$ mothers were not taking folic acid (Table 5).

\section{Table 6: Status of other siblings}

\begin{tabular}{|l|c|c|}
\hline Status & No of cases & \% \\
\hline Affected/ Deceased & 3 & 10 \\
\hline Healthy/ normal & 17 & 57 \\
\hline Not applicable & 10 & 33 \\
\hline
\end{tabular}

It was reported that $57 \%$ patients had normal/ healthy siblings, while $10 \%$ patients had affected or deceased siblings and remaining $33 \%$ were of the first birth order (Table 6).

Table 7: Diagnosis

\begin{tabular}{|l|l|c|c|}
\hline Diagnosis & No of cases & \% \\
\hline \multirow{3}{*}{$\begin{array}{l}\text { Spina bifida } \\
\text { aperta }\end{array}$} & Myelomeningocele & 17 & 57 \\
\cline { 2 - 4 } & Meningocele & 2 & 7 \\
\cline { 2 - 4 } & Myelocele & 1 & 3 \\
\cline { 2 - 4 } & Rachschisis & 2 & 7 \\
\hline \multirow{2}{*}{$\begin{array}{l}\text { Spina bifida } \\
\text { occulta }\end{array}$} & Lipomeningomyelocele & 3 & 10 \\
\cline { 2 - 4 } & $\begin{array}{l}\text { Hemangiomatous patch } \\
\text { with tethered cord }\end{array}$ & 1 & 3 \\
\cline { 2 - 4 } & $\begin{array}{l}\text { Tethered cord with } \\
\text { diastemmatomyelia }\end{array}$ & 1 & 3 \\
\hline $\begin{array}{l}\text { Combined } \\
\text { defects }\end{array}$ & $\begin{array}{l}\text { Myelomeningocele with } \\
\text { dorsal tract }\end{array}$ & 3 & 10 \\
\hline
\end{tabular}

In the present study, $57 \%$ patients were found to have myelomeningocele, $7 \%$ had meningocele, $3 \%$ had myeloceleand $7 \%$ had rachschisis. It was reported that $10 \%$ patients had lipomeningomyelocele, $3 \%$ patients had hemangiomatous patch with tethered cord and $3 \%$ patients had tethered cord with diastemmatomyelia (table 7). The most common type of spinal dysraphism was spina bifida aperta as observed in the patients under study.

Table 8: Surgeries performed

\begin{tabular}{|c|c|c|c|}
\hline \multicolumn{2}{|l|}{ Procedure } & No of cases & $\%$ \\
\hline \multicolumn{2}{|c|}{ Excision repair of defect } & 25 & 84 \\
\hline \multicolumn{2}{|c|}{ Laminectomy and detethering of cord } & 4 & 13 \\
\hline \multicolumn{2}{|c|}{$\begin{array}{l}\text { Laminectomy and dissection of fibrous } \\
\text { spur }\end{array}$} & 1 & 3 \\
\hline \multirow{2}{*}{$\begin{array}{l}\text { Additional } \\
\text { procedure with } \\
\text { primary surgery }\end{array}$} & V-P shunting & 3 & 10 \\
\hline & $\begin{array}{l}\text { Excision of dermal } \\
\text { sinus tract }\end{array}$ & 3 & 10 \\
\hline \multirow{2}{*}{$\begin{array}{l}\text { Additional } \\
\text { procedure in the } \\
\text { follow-up } \\
\text { period }\end{array}$} & V-P shunting & 1 & 3 \\
\hline & $\begin{array}{l}\text { Laminectomy and } \\
\text { detethering of cord }\end{array}$ & 1 & 3 \\
\hline
\end{tabular}

In the current study, $83 \%$ patients underwent excision- repair of defect, $13 \%$ patients underwent laminectomy and detethering of cord, $3 \%$ patients had undergone laminectomy and dissection of fibrous spur. $10 \%$ patients underwent ventriculo-peritoneal shunting along with excision repair of defect and 3\% patients underwent excision of dermal sinus tract. In the follow up period 3 $\%$ patients underwent laminectomy and detethering of cord (Table 8).

Table 9: Post- operative complications

\begin{tabular}{|c|c|c|c|c|}
\hline \multicolumn{3}{|l|}{ Complications } & No of cases & $\%$ \\
\hline \multirow{3}{*}{$\begin{array}{l}\text { Immediate (First } \\
24 \mathrm{hrs)}\end{array}$} & \multicolumn{2}{|l|}{ Vomiting } & 0 & 0 \\
\hline & \multicolumn{2}{|l|}{ Fever } & 2 & 6 \\
\hline & \multicolumn{2}{|l|}{ Seizures } & 1 & 3 \\
\hline \multirow[t]{5}{*}{ Early (1-7 days) } & \multicolumn{2}{|c|}{ Meningitis } & 2 & 6 \\
\hline & \multirow{2}{*}{$\begin{array}{l}\text { Wound } \\
\text { infection }\end{array}$} & Minor & 4 & 14 \\
\hline & & Major & 3 & 10 \\
\hline & \multicolumn{2}{|l|}{ CSF leak } & 4 & 14 \\
\hline & \multicolumn{2}{|c|}{ Shunt blockage } & 1 & 3 \\
\hline \multirow{2}{*}{$\begin{array}{l}\text { Late (after } 7 \\
\text { days) }\end{array}$} & \multicolumn{2}{|c|}{ Hydrocephalus } & 1 & 3 \\
\hline & \multicolumn{2}{|c|}{ Tethered cord } & 1 & 3 \\
\hline
\end{tabular}

In Post-operative study, $6 \%$ patients developed fever, 3\% patients developed seizures in immediate post-operative period. In early post- operative period $6 \%$ patients developed meningitis, $14 \%$ patients developed minor wound infection, whereas, $10 \%$ developed major wound infection, $14 \%$ patients were reported with CSF leakage and 3\% patients developed shunt blockage. In the late post- operative period, $3 \%$ patients developed hydrocephalus and $3 \%$ reported with tethering of cord (Table 9).

Table 10: Outcomes at 3 month post-surgery

\begin{tabular}{|l|c|c|}
\hline Outcome & No of cases & \% \\
\hline Good & 20 & 67 \\
\hline Satisfactory & 6 & 20 \\
\hline Poor & 4 & 13 \\
\hline
\end{tabular}

In the present study, out of 30 patients operated for spinal dysraphism, 67\% patients showed good outcome, 20\% showed satisfactory outcome and $13 \%$ patients showed poor outcome after 3 months of surgery. Mortality rate was recorded to be $13 \%$ (Table 10).

\section{Discussion}

Spinal dysraphism is a congenital anomaly encompassing wide spectrum of neural tube defects. With prenatal screening, the 
incidence is on a decline as the patients can be tested early and further management could be planned accordingly to reduce the subsequent neurological, urological and orthopedic disabilities. In the present study, out of 30 patients, 21 were males and 9 were females. The data showed a higher risk of incidence in male than female. Similar findings were reported by Sherif and Momen, 2017, in a study of sixty patients with open spinal dysraphism, thirty-seven patients $(61.7 \%)$ were males while twenty-three patients $(38.3 \%)$ were females. Kumar and Singh 2003 reported that out of 155 patients of spinal dysraphism, the male to female ratio was 1.5:1. Spinal dysraphism was found to be more prevalent in infants (Choi et al., 2020). In the current study, the maximum number of patients belonged to neonatal age group. In a study done by Rao et al., 2015, the age of the patients ranges from one day to 17 years. The youngest patient was reported to be one day. In the present study, it was reported that the intake of folic acid by mothers reduced the risk of spinal dysraphism. Maternal preconception of folic acid has been found to reduce the risk of spina bifida (Dixon et al., 2019). In the present study, 10\% patients had affected or deceased sibling. The risk of spinal dysraphism is greater if a woman has had previous fetal death (Guida et al., 2009). The commonest site of occurrence of spinal dysraphism was found to be in the lumbo sacral region $(63 \%)$. This is in accordance with the study conducted by Premlal, 2018. He reported lumbosacral region as the most common site of occurrence of spinal dysraphism with $51.85 \%$. In the present study, $30 \%$ patients showed weakness at hip, $50 \%$ patients and weakness in right knee and ankle and $43 \%$ patients reported weakness at left knee and ankle. Iftikhar and De Jesus, 2020, showed motor weakness and sensory deficit in the lower limbs of the patients. Sphinter dysfunction was seen in $30 \%$ patients in the present study. Sphinter dysfunction is reported to be a common occurrence in spinal dysraphism (Wide et al., 2020). In the present study, post-operative improvement was seen in $88 \%$ patients. In a study by Metcalfe et al., 2006, post-operative improvement in $72 \%$ patients was reported. In the current study, $77 \%$ patients showed hydrocephalus (Kafle et al., 2017). The most common associated anomaly with spinal dysraphism is hydrocephalus. Kumar and Singh, 2003 reported that hydrocephalus in $42.59 \%$ patients. Meningomyelocele was seen in $57 \%$ patients in the current study, followed by lipomeningomyelocele in $10 \%$ patients. The patients with lipomeningomyelocele were reported to have normal leg function and continence. The studies support direct injury to the protruding spinal cord as the primary cause of damage and loss of function. In the present study, 3 patients of lipomeningomyelocele were reported to have normal legs. Prenatal screening of fetus by ultrasound has lead to the detection of defect at an early stage in utero (Kumar et al., 2017). In current study, $80 \%$ mothers underwent ultrasound antenatally, out of which $60 \%$ were detected with anomalies. In the present study, $67 \%$ patients showed good outcome post operatively. A study by Borcek et al., 2012 reported $82.2 \%$ patients with good outcome post operatively. In the present study, we report a mortality rate of $13 \%$.

\section{Conclusion}

Spinal dysraphism is the most common type of congenital disability in children faced by pediatric neurosurgeon. Open type of spina bifida is seen to be more prevalent than closed type. From the current study it was concluded that spinal dysraphism is a complex disorder influencing multiple systems of body, thus, requires multidisciplinary approach for management and better outcome. However, surgery remains the treatment of choice along with good post-operative care. Family support remains the most important aspect for the patient's better life.

\section{Ethical approval}

The study was approved by the Institutional Ethics Committee.

\section{List of abbreviations}

AFP: Alpha Feto Protein

HCG: Human Chorionic Gonadotropin

MRI: Magnetic Resonance Imaging

CT: Computed Tomography

CSF: Cerebrospinal Fluid

\section{Conflicts of interest}

None declared

\section{Funding}

No Funding Sources

\section{Authors' contributions}

VKG and BG performed the operative interventions. AB and SS analyzed and interpreted the patients' data regarding the surgical management of spinal dysraphism. All the authors read and approved the final manuscript.

\section{References}

[1] Aurel, R., \& Livii, V. (2020). Spinal Dysraphism of Lumbosacral Area in Infants: Aspects of Surgical Treatment. J Pediatr Neonatal, 2(1), 1-6.

[2] Blount, J. P., George, T. M., Koueik, J., \& Iskandar, B. J. (2019). Concepts in the neurosurgical care of patients with spinal neural tube defects: An embryologic approach. Birth defects research, 111(19), 1564-1576.

[3] Börcek, A. Ö., Öcal, Ö., Emmez, H., Zinnuroğlu, M., \& Baykaner, M. K. (2012). Split cord malformation: experience from a tertiary referral center. Pediatric neurosurgery, 48(5), 291-298.

[4] Bradko, V., Castillo, H., Janardhan, S., Dahl, B., Gandy, K., \& Castillo, J. (2019). Towards guideline-based management of tethered cord syndrome in spina bifida: a global health paradigm shift in the era of prenatal surgery. Neurospine, 16(4), 715.

[5] Choi, S. J., Yoon, H. M., Hwang, J. S., Suh, C. H., Jung, A. Y., Cho, Y. A., \& Lee, J. S. (2020). Incidence of occult spinal dysraphism among infants with cutaneous stigmata and proportion managed with neurosurgery: a systematic review and meta-analysis. JAMA network open, 3(7), e207221-e207221.

[6] Dias, M. S., \& Rizk, E. B. (2019). Normal Early Human Neural Development. Occult Spinal Dysraphism, 17.

[7] Dixon, M., Kancherla, V., Magana, T., Mulugeta, A., \& Oakley Jr, G. P. (2019). High potential for reducing folic acid-preventable spina bifida and anencephaly, and related stillbirth and child mortality, in Ethiopia. Birth defects research, 111(19), 1513-1519.

[8] Eagles, M. E., \& Gupta, N. (2020). Embryology of Spinal Dysraphism and its Relationship to Surgical 
Treatment. Canadian Journal of Neurological Sciences, 47(6), 736-746.

[9] Gordon, C. R., Wolff, A., Santiago, G. F., Liebman, K., Veznedaroglu, E., Vrionis, F. D.,... \& Luciano, M. (2019). First-in-human experience with integration of a hydrocephalus shunt device within a customized cranial implant. Operative Neurosurgery, 17(6), 608-615.

[10] Gotha, L., Pruthi, V., Abbasi, N., Kulkarni, A. V., Church, P., Drake, J. M., ... \& Van Mieghem, T. (2020). Fetal spina bifida: what we tell the parents. Prenatal diagnosis, 40(12), 1499-1507.

[11] Guida, M., Sardo, A. D. S., Carbone, M. M., Natella, V., Falleti, J., \& Nappi, C. (2009). Spinal dysraphism in an early missed abortion: embryofetoscopic diagnosis. Journal of minimally invasive gynecology, 16(6), 768-771.

[12] Iftikhar, W., \& De Jesus, O. (2020). Spinal Dysraphism and Myelomeningocele. StatPearls

[13] Kafle, P., Shilpakar, S. K., Sharma, M. R., Sedain, G., Pradhanang, A. B., Shrestha, R. K.,... \& Khanal, B. (2017). Spinal Dysraphism: Common Entity in Pediatric Neurosurgery. Nepal Journal of Neuroscience, 14(1), 26.

[14] Kumar, J., Afsal, M., \& Garg, A. (2017). Imaging spectrum of spinal dysraphism on magnetic resonance: A pictorial review. World journal of radiology, 9(4), 178.

[15] Kumar, R., \& Singh, S. N. (2003). Spinal dysraphism: trends in northern India. Pediatric neurosurgery, 38(3), 133-145.

[16] Metcalfe, P. D., Luerssen, T. G., King, S. J., Kaefer, M., Meldrum, K. K., Cain, M. P.,... \& Casale, A. J. (2006). Treatment of the occult tethered spinal cord for neuropathic bladder: results of sectioning the filum terminale. The Journal of urology, 176(4S), 1826-1830.

[17] Peralta, C. F., Botelho, R. D., Romano, E. R., Imada, V., Lamis, F., Júnior, R. R.,... \& de Salles, A. A. (2020). Fetal open spinal dysraphism repair through a minihysterotomy: influence of gestational age at surgery on the perinatal outcomes and postnatal shunt rates. Prenatal diagnosis, 40(6), 689-697.

[18] Prakash, P., Dhandapani, M., Ghai, S., Singh, N. V., \& Dhandapani, S. (2018). Quality of life among children who had undergone ventriculoperitoneal shunt surgery. Journal of pediatric neurosciences, 13(2), 189.

[19] Premlal, K. V. (2018). A Retrospective Analysis of Clinical Profile and Surgical Outcome in Patients with Spinal Dysraphism at Tertiary Care Center.
[20] Premlal, K. V. (2018). A Retrospective Analysis of Clinical Profile and Surgical Outcome in Patients with Spinal Dysraphism at Tertiary Care Center.

[21] Rao, B. H., Prasad, K. V., Sekhar, K. I., \& Sekhar, B. R. (2015). Study on spinal dysraphism in tertiary care centre, andhra medical college, Visakhapatnam. J Evid Based Med Healthc, 2(6).

[22] Reghunath, A., Ghasi, R. G., \& Aggarwal, A. (2019). Unveiling the tale of the tail: an illustration of spinal dysraphisms. Neurosurgical review, 1-18.

[23] Sherif, A., \& Momen, M. (2017) Surgical management of open spinal dysraphism: 5 years experience in Upper Egypt-a multi-centre study.

[24] Sims-Williams, H. J., Sims-Williams, H. P., Kabachelor, E. M., \& Warf, B. C. (2017). Quality of life among children with spina bifida in Uganda. Archives of disease in childhood, 102(11), 1057-1061.

[25] Szopa, A., Domagalska-Szopa, M., Siwiec, A., \& Kwiecień-Czerwieniec, I. (2021). Effects of whole-body vibration-assisted training on lower limb blood flow in children with myelomeningocele. Frontiers in Bioengineering and Biotechnology, 9.

[26] Thompson, D. N. (2014). Spinal dysraphic anomalies; classification, presentation and management. Paediatrics and Child Health, 24(10), 431-438.

[27] Trapp, B., de Andrade Lourenção Freddi, T., de Oliveira Morais Hans, M., Fonseca Teixeira Lemos Calixto, I., Fujino, E., Alves Rojas, L. C., ... \& Dalul Gomez, G. (2021). A Practical Approach to Diagnosis of Spinal Dysraphism. RadioGraphics, 200103.

[28] Tuite, G. F., Thompson, D. N., Austin, P. F., \& Bauer, S. B. (2018). Evaluation and management of tethered cord syndrome in occult spinal dysraphism: Recommendations from the international children's continence society. Neurourology and urodynamics, 37 (3), 890-903.

[29] Venkataramana, N. K. (2011). Spinal dysraphism. Journal of pediatric neurosciences, 6 (Suppl1), S31.

[30] Warner, H. M., Batty, R., Warner, F. M., Fanou, E. M., \& Griffiths, P. D. (2019). T2 prolongation in the cerebellar vermis on prenatal MRI of fetuses with Chiari 2 malformations. Clinical radiology, 74(5), 408-e19.

[31] Wide, P., Duchén, K., Mattsson, S., \& Mattsson, G. G. (2020). Four-hour voiding observation with provocation test reveals significant abnormalities of bladder function in newborns with spinal dysraphism. Journal of Pediatric Urology, 16(4), 491-e1 